\title{
Non-Executive Chairman, Audit Quality and Earnings Management
}

\author{
Aditi Shams ${ }^{1}$ \\ ${ }^{1}$ Assistant Professor, University of Dhaka, Bangladesh \\ Correspondence: Aditi Shams, Assistant Professor, University of Dhaka, Bangladesh. E-mail: \\ aditishams@du.ac.bd \\ Received: October 14, 2019 \\ Accepted: January 5, 2020 \\ Online Published: February 15, 2020 \\ doi:10.5539/ijbm.v15n3p50 \\ URL: https://doi.org/10.5539/ijbm.v15n3p50
}

\begin{abstract}
The purpose of this paper is twofold, first, it examines the association of non-executive chairman and the quality of financial earnings and second, it examines the role of audit quality and non-executive chairman in earnings quality. This paper uses the modified jones model and the performance adjusted modified Jones model considering two cash flow methods of total accrual and perform regression analysis on the energy sector firms from the year 2010-2012. The study result does not find any significant association of earnings management and non-executive director and audit quality in the Australian context. This finding raises concerns regarding the effectiveness of such a corporate governance mechanism to maximize monitoring over the operation of the firm.
\end{abstract}

Keywords: non-executive chairman, audit quality, earnings management

JEL Classification Code: M4 Accounting and Auditing

\section{Introduction}

Recent cases of inappropriate accounting practices in Australia have focused attention on the need for strong corporate governance mechanisms (Davidson et al. 2005). This study will explore the relationship between the board and external auditor related corporate governance mechanisms and earnings management by the industrial sector in listed companies in Australia from the period of 2007-2012. This study will thus focus on both internal and external monitoring role of corporate governance. This paper will examine the association of earnings management with chairman independence and audit quality, which are commonly referred to as internal and external governance mechanisms for good governance.

The examination of the association between internal governance structures and the practice of earnings management in Australian firms is motivated by- first, this paper extends the duality role of chairman and CEO to examine whether the non-executive chairman is associated with earnings management or not; secondly, audit quality has an important role to play in ensuring the accuracy and reliability of financial information and thirdly, these results will have important implications for the government, accounting standard setters and regulators.

The main empirical test will be using the discretionary accruals and absolute discretionary accruals to measure earnings management. The findings do not find evidence of an association between the non-executive chairman, external auditor quality and earnings of the firm. This result raises concerns regarding the effectiveness of the corporate governance mechanisms to control firm operation. The interpretation of these results might be subjected to several limitations that require special attention. The remainder of this paper is divided into five sections. Section 2 will provide a brief theoretical background for the study and will develop hypotheses. Section 3 will outline the research methodology and will discuss the measurements used. Section 4 reports the results, and Section 5 concludes by discussing the findings and finally, Section 6 highlights the limitations and outlines the scope of future research.

\section{Literature Review, Research Question, and Hypothesis Development}

The Australian Securities and Exchange (ASX) Principles of Good Governance and Best Practice Recommendations, recommends separation of the chairman and CEO/Managing director role to avoid concentration of power and ensure better monitoring (ASX, 2010). It is believed that this separation will work as a better monitoring device over the management to ensure a balance of power and authority and will minimize the agency cost (Ow-Yong \& Guan, 2000). The agency theory supports the idea that if two separate individuals hold the position of chairman and CEO that will allow efficient monitoring and thus protecting shareholders' 
interest. On the contrary, stewardship theorists of corporate governance believe that the dual role of chairman and $\mathrm{CEO}$ will enhance the decision-making process and will allow the firms improved performance (Harris \& Helfat, 1998).

Previous studies on leadership structure have documented weak, insignificant relationship CEO duality (CEO duality refers to the chairman of the board is also the CEO of the firm) and financial quality (Kao and Chen, 2004; Davidson et al. 2005). Although the separation of chairman role and CEO role (CEO and Chairman different person) seems important, researchers argue that this separation does not confirm the independence of the chairman, leading to the independence of the board. Arguably, the chairman who holds an executive position in the same firm or is an internal member of the firm is more likely to engage in earnings management activity than chairman who is an independent non-executive director. Therefore, this paper will try to extend the past studies on the duality of the chairman by proposing the following research question:

\section{Do listed firms with the non-executive chairman on the board are less likely to engage in earnings management activity?}

Past studies have shown mixed findings in this regard. Kao \& Chen (2004) and Davidson et al. (2005) fail to find any empirical support on the association between chairman duality and earnings management. However, Lin (2011) has found a significant association with chairman independence and discretionary accrual. Again, Cadbury Committee corporate governance guidelines (1992) also recommend the independence of the chairman of the board as a part of the internal governance mechanism. It assumes that boards' ability to perform an independent monitoring role is weakened when the chairman is also the executive board member and which in turn can affect the quality of financial indicators. These lead to our first hypotheses:

\section{H1: Firms with non-executive chairman are associated with less earnings management.}

Again, there is international evidence that Big4 audit firms provide -high-quality audit services, higher accuracy concerning future stock returns. (Lin, 2011). Investors also tend to have a perception that financial reports audited by Big4 audit firms have higher quality. However, the findings are mixed. DeAngelo (1981) analytically demonstrates that large audit firms (Big 4 auditors) are likely to provide high-quality audits than small audit firms. Wu and $\mathrm{Li}$ (2006) find that firms audited by Big 4 are associated with a lower level of earnings management, measured by discretionary accruals. These studies generally suggest that the Big four auditors' higher levels of audit quality should be associated with lower levels of earnings management.

On the contrary, Liu and Zhou (2007) find that the association is statistically insignificant. Many studies have used audit firm size (Big4 vs the Non-Big 4) as a proxy for audit quality (Davidson and Neu, 1993; Becker et al., 1998; Cai et al., 2005). Though there is less evidence of conformity of the audit quality of big4 and non-big4 firms, the external audit quality is considered to be an important external corporate governance mechanism in monitoring the financial quality of the firm. These leads to the next two hypotheses:

H2 (i): Firms audited by Big4 firms are associated with less earnings management.

H2 (ii): Ceteris Paribas, firms audited by Big4 firms, and having non-executive chairman on the board are associated with less earnings management.

\section{Research Methodology}

\subsection{Sample Selection and Assumptions}

This study used the Australian listed firms from 2007-2012 across the following eight GICS sectors-consumer discretionary, consumer staples, energy, materials, industries, health care, information technology, and telecommunications. First, a total of 12958 observations are pulled from the database from the years 1989-2013 considering the scope of this paper (relevant year and industry). Second, this paper created a dummy variable to avoid the issue of the same financial year due to the change in balance-sheet date and excluded the firm-year observations that contain two or more balance-sheet date in the same financial year. Third, sample data containing invalid, missing value for the key variables-total asset, total liability, lagged total assets, operating revenue, reported NPAT before abnormal, reported NPAT after abnormal and net cash from operations were also excluded from the sample. Further, the sample data that shows zero total assets are also excluded from the final dataset resulting in a total of 4653 firm-year observations for eight sectors from the year 2007-2012.

As this paper specifically examines the association between executive chairman, audit quality, and earnings management, data regarding all the firms in 'Energy Sector' from the year 2010-2012 were collected resulting in a total of 293 firm-year observations. This is considerably a small sample considering the whole number of firms in the energy sector. This paper classifies the non-executive chairman and audit firm (Big 4) based on the single 
year 2012 and assumes that the position of the chairman and the audit firm remained the same in the previous period. This might result in a bias in the result as the changes within a firm during the mentioned period is not considered.

\subsection{Variable Measurements and Model Specification}

\subsubsection{Discretionary Accrual Model}

This paper applies a cross-sectional modified Jones model (hereafter, MJ) that separates total accruals (TA) into discretionary accruals (DAC) and non-discretionary accruals (NDAC) to detect earnings management as per Dechow et al. (1995). Dechow et al. (1995) argue that the modified Jones model exhibits the most powerful test in detecting earnings management compared to the original Jones (1991) model. MJ model assumes that the non-discretionary component of total accrual is a function of the changes in revenues, changes in receivables, and the level of property, plant and equipment (PPE) which drives working capital requirements and depreciation charges. This paper also used the performance-adjusted modified Jones model (PJ) in estimating earnings management. As per Kothari et al. (2005), the performance-adjusted model has less misspecification compared to other models.

This paper uses a cash-flow approach in estimating total accrual, which is considered to be superior to the balance-sheet approach (Hribar \& Collins, 2002). In this approach, the TA is estimated as follows-

Method 1: TA = Operating Profit after Tax ( GICS item 8020 ) - Cash from operating activities (GICS item 9100)

Method 2: TA = Operating Profit after Tax -excluding Net Abnormal items (GICS item 8020) - Cash from operating activities (GICS item 9100)

This paper uses linear regression to estimate discretionary accruals under the two model in two methods each, totaling four models- modified Jones Model, with TA estimated using method 1 (MJ1) and with TA using method 2 (MJ2), Performance-adjusted modified Jones model, with TA estimated in method 1(PJ1) and TA estimated in method 2 (PJ2).

Modified Jones Model

$$
\mathrm{TA}_{i t}=\beta_{0}+\beta_{1}\left(\frac{1}{\text { Assets }_{i t-1}}\right)+\beta_{2}(\Delta \text { Sales })_{i t}+\beta_{3} P P E_{i t}+\epsilon_{i t}
$$

Performance-adjusted modified Jones model

$$
\mathrm{TA}_{i t}=\beta_{0}+\beta_{1}\left(\frac{1}{\text { Assets }_{i t-1}}\right)+\beta_{2}(\Delta \text { Sales })_{i t}+\beta_{3} P P E_{i t}+\beta_{4} R O A_{i t}+\epsilon_{i t}
$$

Here, $\left(\frac{1}{\text { Assets }_{\text {it-1 }}}\right)$ is the inverse of lagged total assets

$\Delta$ Sales is change in operating revenue minus change in account receivable, scaled by lagged total asset PPE is the gross property, plant \& equipment, scaled by lagged total assets.

ROA is EBIT scaled by lagged total asset (Note 1).

\subsubsection{Earnings Management}

This paper uses linear regression analysis to test the association between the dependent variable of earnings quality and the independent variable- non-executive chairman and audit firm.

$$
\mathrm{DAC}=\beta_{0}+\beta_{1} \quad N E x d+\beta_{2} \text { BigN }+\beta_{3} \quad N E x d * B i g N+\beta_{4} \text { LnTAsset }+\beta_{5} \text { Lev }+\beta_{6} C F O+\epsilon
$$

Here,

$\mathrm{DAC}=$ discretionary accrual measured by modified Jones model $(\mathrm{MJ})$ and Performance-adjusted modified Jones model (PJ)

NExd=dummy variable for chairman duality, 1 if Non-executive director, 0 if the executive director

BigN=dummy variable for audit quality, 1 if Big 4 audit firm, 0 if non-Big 4 audit firm

LnTAsset $=\log$ of total asset

Lev= Leverage (ratio of total debt to total asset) 
$\mathrm{CFO}=$ cash flow from operation

$\mathrm{NExd} * \mathrm{BigN}=$ interaction of non-executive director and BigN

The main variables, non-executive chairman and Big4 audit firm, is treated as a dummy variable in this paper. Thus, the non-executive chairman is assigned 1; the executive chairman is assigned 0 and firms that belong to Big4 audit firms (,KPMG Deloitte, PricewaterhouseCoopers, and (Young \& Ernstare assigned 1 and firms that belong to non-audit firms is assigned 0 . In the above model, the independent variables are NExd and BigN and the control variables are - firm size (lnTAsset), leverage (Lev) and cash flow from operating activity (CFO). Previous studies have used several control variables for the corporate governance mechanism study. Firm size, leverage, and cash flow are considered to the most used control variable. However, due to the unavailability of data, this study could not use other control variables considered to be important for studies of similar interest.

In this paper, DAC is obtained by the regression of unstandardized residuals (URES) based on the modified Jones Model and Performance -adjusted modifies Jones. In addition to that, separate regression is performed on the absolute value of unstandardized residuals (ABRES) based on both models.

\section{Results}

\subsection{Descriptive Statistics}

The descriptive statistics for whole 4653 observations for the period of 2007 to 2012 before and after exclusion of unstandardized residuals greater than three times the standard deviation for each variable under discretionary accrual is presented in Table 1. The table shows that after the exclusion of seventy-four outliers in the unstandardized residual method, the maximum total accrual under both method 1 and method has decreased substantially. From Table 1 it is observed that this change has occurred largely due to the exclusion of outliers that has the lowest ROA.

Table 2 presents descriptive statistics for the measurement of total accruals for the sector of interest 'Energy' sector for the year of interest 2010-2012. Panel A shows statistics before

Table 1. Descriptive statistics for the measurement of total accruals (all sectors), 2007-2012

Panel A: before exclusion of Unstandardized Residuals $>3 *$ Std.Deviation

\begin{tabular}{|c|c|c|c|c|c|}
\hline & $\mathrm{N}$ & Mean & Std. Deviation & Minimum & Maximum \\
\hline TA $(\operatorname{method} 1)$ & 4653 & -.1526 & 3.6173 & -215.0231 & 24.1681 \\
\hline TA (method 2) & 4653 & -.1715 & 4.2060 & -260.5603 & 18.81285 \\
\hline$\Delta$ Sales & 4653 & .7894 & 44.7570 & -9.6790 & 3050.491 \\
\hline 1/laggedTAsset & 4653 & $1.48 \mathrm{e}-07$ & $3.03 e-06$ & $7.75 \mathrm{e}-12$ & .0002004 \\
\hline PPE & 4653 & .5935 & 5.9688 & .0000437 & 399.7195 \\
\hline ROA & 4653 & -.0305 & 7.9317 & -229.0257 & 486.0749 \\
\hline \multicolumn{6}{|c|}{ Panel B: after exclusion of Unstandardized Residuals $>3$ Std.Deviation } \\
\hline & $\mathrm{N}$ & Mean & Std. Deviation & Minimum & Maximum \\
\hline TA (method 1) & 4579 & -.1062 & 1.7016 & -113.8048 & 2.8325 \\
\hline TA (method 2) & 4579 & -.1144 & 1.7072 & -113.8048 & 2.8325 \\
\hline$\Delta$ Sales & 4579 & .7677 & 45.0338 & -6.5399 & 3050.491 \\
\hline 1/laggedTAsset & 4579 & $1.11 \mathrm{e}-07$ & $2.96 \mathrm{e}-06$ & $7.75 \mathrm{e}-12$ & .0002004 \\
\hline$P \quad E$ & 4579 & .5687 & 5.9438 & .0000437 & 399.7195 \\
\hline ROA & 4579 & .0494 & 7.1903 & -9.1630 & 486.0749 \\
\hline
\end{tabular}


Table 2. Descriptive statistics for measurement of total accruals (Energy Sector, 2010-2012)

\begin{tabular}{|c|c|c|c|c|c|}
\hline \multicolumn{6}{|c|}{ Panel A: before exclusion of Unstandardized Residuals $>3$ Std.Deviation } \\
\hline & $\mathrm{N}$ & Mean & Std. Deviation & Minimum & Maximum \\
\hline TA (method 1$)$ & 293 & -.1315819 & .3235 & -2.394068 & 2.352868 \\
\hline TA (method 2) & 293 & -.1186603 & .3823249 & -2.394068 & 2.815867 \\
\hline$\Delta$ Sales & 293 & .0209622 & .5580094 & -2.997428 & 7.526208 \\
\hline 1/laggedTAsset & 293 & $9.36 \mathrm{e}-08$ & $2.76 \mathrm{e}-07$ & $3.75 \mathrm{e}-11$ & $2.91 \mathrm{e}-06$ \\
\hline PPE & 293 & .6426849 & .709755 & .0006511 & 6.148722 \\
\hline ROA & 293 & -.1884075 & .7168364 & -3.968311 & 7.794192 \\
\hline \multicolumn{6}{|c|}{ Panel B: after exclusion of Unstandardized Residuals $>3 *$ Std.Deviation } \\
\hline & $\mathrm{N}$ & Mean & Std. Deviation & Minimum & Maximum \\
\hline TA (method 1) & 288 & -.1349939 & .2846312 & -2.394068 & 1.12879 \\
\hline TA (method 2) & 288 & -.1324852 & .3053142 & -2.394068 & 1.354723 \\
\hline$\Delta$ Sales & 288 & .0030034 & .3205771 & -2.997428 & 2.2917 \\
\hline 1/laggedTAsset & 288 & $6.93 \mathrm{e}-08$ & $1.56 \mathrm{e}-07$ & $3.75 e-11$ & $1.06 \mathrm{e}-06$ \\
\hline PPE & 288 & 6486823 & .7125566 & .0006511 & 6.148722 \\
\hline $\mathrm{ROA}$ & 288 & -.18356 & .4381694 & -3.330972 & 1.496506 \\
\hline \multicolumn{6}{|c|}{ Panel C: after exclusion of Cook's distance $<3$} \\
\hline & $\mathrm{N}$ & Mean & Std. Deviation & Minimum & Maximum \\
\hline TA (method 1) & 289 & -.1353838 & .2842139 & -2.394068 & 1.12879 \\
\hline TA (method 2) & 289 & -.1222833 & .3506735 & -2.394068 & 2.815867 \\
\hline$\Delta$ Sales & 289 & -.0046702 & .3455868 & -2.997428 & 2.2917 \\
\hline 1/laggedTAsset & 289 & $6.92 \mathrm{e}-08$ & $1.55 \mathrm{e}-07$ & $3.75 \mathrm{e}-11$ & $1.06 \mathrm{e}-06$ \\
\hline PPE & 289 & .6486823 & .7118436 & .0006511 & 6.148722 \\
\hline ROA & 289 & -.1833271 & .4374259 & -3.330972 & 1.496506 \\
\hline
\end{tabular}

exclusion of observations with any residuals higher than three times the standard deviation and Panel B shows statistics after exclusion observations of such residuals and Panel $\mathrm{C}$ shows statistics after exclusion of observations through 'cook's distance. The detail description of how the cook's distance will be analyzed is discussed in the next section. Table 2 shows that only 5 outliers are excluded and the maximum value for change in sales and ROA is reduced in panel B and panel B also shows similar outcomes with deduction of 4 influential observations. This also confirms that the change is mainly due to outliers in ROA. Both in 'unstandardized residual' and cook's distance method the outcome is similar with no major observable deviations

Table 3 below presents descriptive statistics on for unstandardized residuals under the four models for all sectors from the year 2007 to 2012. The table showed that all the models have a mean value of the residual (error term) very close to zero. The histogram and scatter diagram shown in figure -P1 enclosed, shown that the error terms are fairly normally distributed and the scatter diagram also does not show any obvious patterns other than some outliers. So, from the normality test, we can assume that the residual distribution is fairly normal with no obvious departure from the assumption of independence. So, the residuals conform to the assumptions of OLS regression.

Table 3. Descriptive statistics for unstandardized residuals (all sector, 2007-2012)

\begin{tabular}{llllll}
\hline & $\mathrm{N}$ & Mean & Std. Deviation & Minimum & Maximum \\
\hline MJ1 & 4653 & $-4.87 \mathrm{e}-11$ & 1.722769 & -59.6587 & 50.06977 \\
MJ2 & 4653 & $-8.21 \mathrm{e}-10$ & 2.045043 & -72.53552 & 61.20715 \\
PJ1 & 4653 & $-2.93 \mathrm{e}-10$ & .7003895 & -6.905423 & 36.57295 \\
PJ2 & 4653 & $-1.01 \mathrm{e}-10$ & .7652219 & -8.973059 & 33.17713 \\
\hline
\end{tabular}

MJ1=Modified Jones Model-method 1

MJ2= Modified Jones Model-method 2

PJ1= Performance matched Modified Jones model-method 1

PJ2= Performance matched Modified Jones model-method 2 
Table 4 reports the descriptive statistics of the continuous and dichotomous variables used in this study for all the firm-year observations in the energy sector from the year 2010 to 2012(a total of 293 firm-year observations). This table shows various dependent variables of discretionary accrual measures (unstandardized residuals and the absolute value of unstandardized residuals) under the four models namely MJ1, MJ2, PJ1 and PJ2. The mean values of unstandardized residuals are slightly lower in all four methods compared to the mean values under absolute unstandardized residuals. In terms of non-executive board chairman in the energy sector, more than half of the board members are non-executive (nearly 79 percent) and more than half of the audit firms are Big4. From the descriptive statistics, we can assume that the independent variables have favorable percentages to run a regression and the observations are not biased in any direction.

Table 4. Descriptive statistics for dependent, independent and control variables for 'energy sector $(\mathrm{N}=293)$

\begin{tabular}{lllll}
\hline & Mean & Std. Deviation & Minimum & Maximum \\
\hline MJ1 & -.03452 & .9691 & -1.0654 & 9.7377 \\
MJ2 & .00682 & 1.17209 & -.97404 & 11.871 \\
PJ1 & .00236 & .4156 & -3.5042 & 2.6991 \\
PJ2 & .05127 & .5469 & -4.9118 & 3.3902 \\
Abs_MJ1 & .4196 & .8739 & .00062 & 9.7377 \\
Abs_MJ2 & .4966 & 1.0613 & .00052 & 11.871 \\
Abs_PJ1 & .2207 & .35197 & .00097 & 3.5042 \\
Abs_PJ2 & .2736 & .47601 & .00022 & 4.9118 \\
Big 4 & .5338 & .49979 & 12.745 & 24.054 \\
NExc_Chair & .7932 & .40575 & 0 & 1 \\
Leverage & .3931 & .68423 & 0 & 1 \\
CFO & $7.10 \mathrm{e}+07$ & $3.39 \mathrm{e}+08$ & $-5.89 \mathrm{e}+08$ & $3.35 \mathrm{e}+09$ \\
Log_T Asset & 18.1968 & 2.2656 & -3.3910 & 3.7621 \\
\hline
\end{tabular}

Table P4 in the Appendix shows the descriptive statistics of the outlier observations. Out of the 74 outliers energy sector contains only five outliers. These outliers are with a higher level of mean, standard deviation and maximum value.

\subsection{Correlation Analysis}

Table 5, Panel A shows the Pearson Correlation Matrix for all sectors across the year 2007-2012. This correlation is performed after the exclusion of outlier selected by 'unstandardized residual' and cook's distance. These selection criteria will be discussed in the next section. Concerning the correlation among variables in the modified Jones model (MJ) and Performance matched modified Jones model, the correlation matrix tested in the study confirms no multicollinearity exists between variables except with ROA and lagged total asset (0.52). Additionally, panel B reports Pearson Correlation Matrix for the energy sector for the year 2010-2012. The cash flow from operating activity (CFO) is averagely correlated with the total assets of the firm. Again, there is a fir correlation between Big4 and the total asset of the firm. So, multicollinearity can be a concern. However, Davidson et al. (2005) also revealed similar concerns with extreme earnings and cash flows in the Australian context. 
Table 5. Correlation matrix

Panel A: Pearson Correlation Matrix for all sectors across the year 2007-2012

\begin{tabular}{|c|c|c|c|c|}
\hline & 1/lagTAsset & $\Delta$ Sales & PPE & ROA \\
\hline 1/lagTAsset & 1 & & & \\
\hline$\Delta$ Sales & -0.842 & 1 & & \\
\hline PPE & $-0.1543 * *$ & $0.1784 * *$ & 1 & \\
\hline ROA & $-0.7350 * *$ & 0.0959 & $0.2287 * *$ & 1 \\
\hline
\end{tabular}

Panel B: Pearson Correlation Matrix for energy sectors across the year 2010-2012

\begin{tabular}{|c|c|c|c|c|c|}
\hline & LogTAsset & Big4 & NExchair & leverage & $\mathrm{CFO}$ \\
\hline LogTAsset & 1 & & & & \\
\hline Big4 & $.4952 * *$ & 1 & & & \\
\hline NExchair & $.2937 * *$ & 0.1425 & 1 & & \\
\hline leverage & .0982 & -0.0485 & -0.0336 & 1 & \\
\hline $\mathrm{CFO}$ & $.5218 * *$ & $0.2407 * *$ & $.2248 * *$ & -0.0525 & 1 \\
\hline
\end{tabular}

Note. ${ }^{*}$ p-value is significant at the 0.05 level.

\subsection{Multivariate Analysis}

This paper has performed unstandardized residuals (URES) based on the modified Jones model and performance-matched modified Jones model. Additionally, separate regression is performed on the absolute value of unstandardized residuals (ABRES) based on both models. Before this analysis, two separate steps have been performed to exclude extreme values of URES and ABRES. First, this paper excludes the sample firms whose residuals from the initial regressions are more than three times the standard deviation. This step excludes the sample firms to minimize the number of outliers. Tabachnick and Fidell (2007) define outliers as the observations with standardized residuals above 3. Second, this paper selects only cases where 'Cook's Distance' is less than 3. Cook's distance helps to check whether any strange case is having undue influence on the results for the model as a whole or not. This paper uses cooks distance less than s due to the large sample size.

Table 6 below shows regression results for the two models under two methods (total four) before the exclusion of outliers for the energy sector from the years 2010-2012. It can be seen that the R square for the model PJ1 and PJ2 is much higher than model MJ1 and MJ2. The significance level for PJ1 and PJ2 is also higher than the other two models. This might mean that the performance adjusted modified Jones model has more explanatory power than the other two models. 
Table 6. Regression results for the energy sector from the year 2010-2012

Regression results (MJ1)

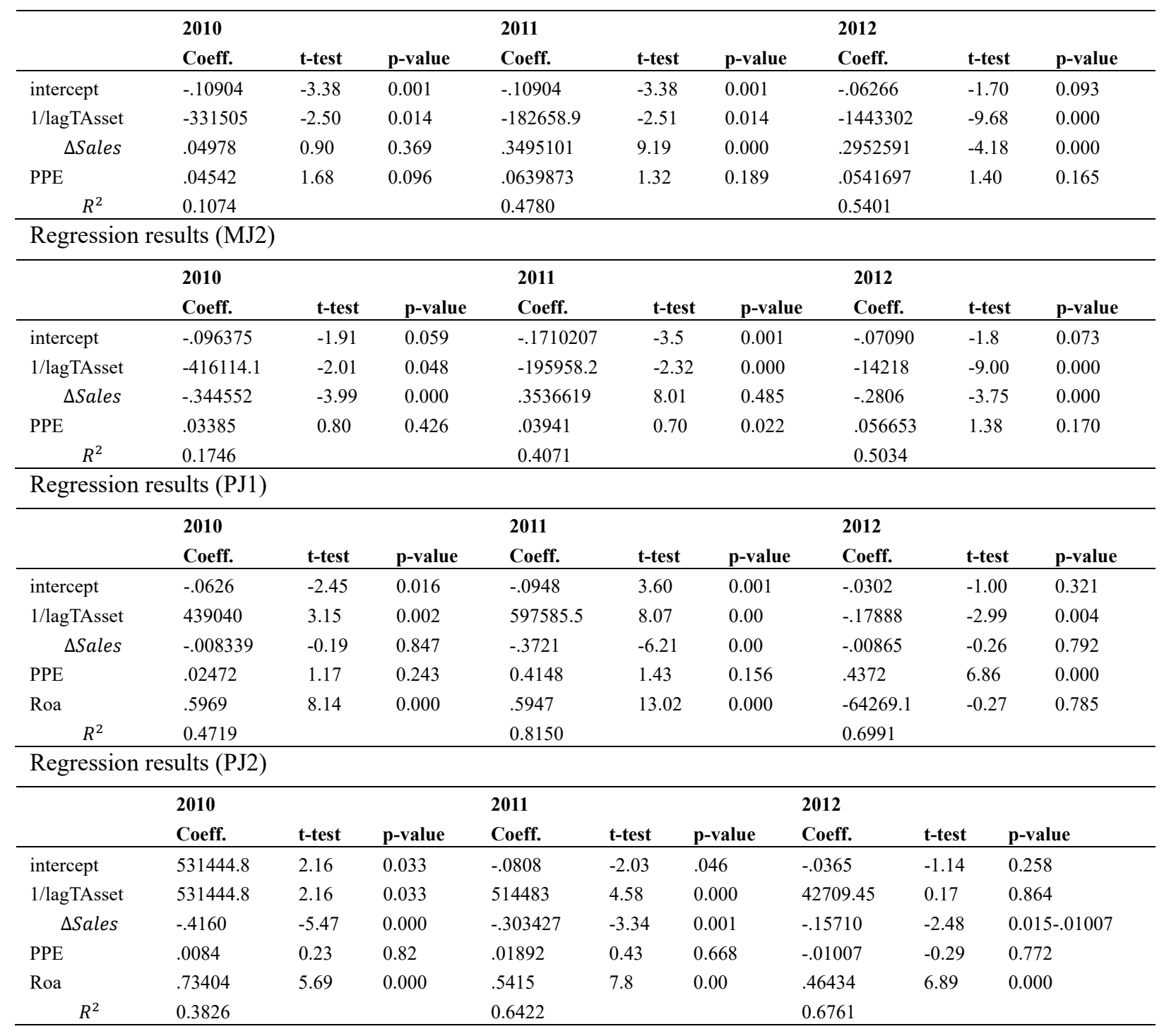

Table 7 shows the regression results of the four models for the energy sector after the exclusion of sample firms whose residuals from the initial regression are more than 3 standard deviations from zero. After excluding the value the regression result shows higher $\mathrm{R}$ square value across four models from the year 2010 to 2012 . The detail significance level is shown in Table P2 in the appendix shows that the significance level has increased. Overall, by excluding the outliers through unstandardized residual the results do not show can significant changes compared to the $\mathrm{R}$ square value of the original residual. As the outlier only amounts to a small number considering the overall sample size, this might be a reason for this smaller change.

Table 7. Regression results for the energy sector from the year 2010-2012 (after unstandardized residuals $<=3$ )

\begin{tabular}{llll}
\hline & $\mathbf{2 0 1 0}$ & $\mathbf{2 0 1 1}$ & $\mathbf{2 0 1 2}$ \\
\hline MJ1 & 0.1042 & 0.2971 & 0.4991 \\
MJ2 & 0.1049 & 0.2345 & 0.4606 \\
Pj1 & 0.4765 & 0.7247 & 0.7191 \\
Pj2 & 0.4691 & 0.4824 & 0.6959 \\
\hline
\end{tabular}

Note. Above table reports, the R squared values. 
Table 8 reports the regression results of the four models for the energy sector from the years 2010-2012 after the exclusion of observations whose residuals have a cook distance greater than three. The $\mathrm{R}$ square across is quite similar except for a slight change in MJ2 and PJ2 in the year 2011. This might be the case because of the outlier in the year 2011. Again, PJ1 and PJ2 show much higher R square and most of the variables show the significant statistical level (Table P3, Appendix)

Table 8. Regression results for the energy sector from the year 2010-2012 (only considering observations with cook distance $<3$ )

\begin{tabular}{llll}
\hline & $\mathbf{2 0 1 0}$ & $\mathbf{2 0 1 1}$ & $\mathbf{2 0 1 2}$ \\
\hline MJ1 & 0.1042 & 0.1080 & 0.4991 \\
MJ2 & 0.1049 & 0.0799 & 0.4606 \\
Pj1 & 0.4765 & 0.7241 & 0.7191 \\
Pj2 & 0.4691 & 0.4813 & 0.6959 \\
\hline
\end{tabular}

Note. Above table reports, the $\mathrm{R}$ squared values.

This part of the paper will do the test for the three hypotheses. After the exclusion of extreme values of URES and ABRES, the observations are reduced to 288 firm-years. Table 9 shows regression results for unstandardized residuals for the energy sector from the year 2010-2012. The results show that there is not sufficient evidence to reject the null hypothesis. Neither Big4 audit firms nor the non-executive chairman has a significant association with earnings management at the 5percent level of the p-value. This result is consistent with Kao and Chen (2004) and Davidson et al. (2005) that fail to find any significant association of non-executive chairman and earnings management. The result of the association between Big 4 audit firm and earnings management is also not statistically significant which confirms prior study findings (Lin, 2011). This paper can only find the relationship between CFO and earnings management but no other control variables seem to have an association with earnings management. Again, on conformity with prior findings, this regression analysis also shows that the performance adjusted modified Jones model has a greater R square than the modified Jones model.

Table 9. Regression results for unstandardized residuals (URES) (Energy sector, 2010-2012)

\begin{tabular}{lllll}
\hline Variable & MJ1 & MJ2 & PJ1 & 0.048 \\
Big4 & 0.270 & 0.524 & 0.780 & 0.531 \\
NExChair & 0.531 & 0.681 & 0.161 & 0.464 \\
Big4*NExChair & 0.446 & 0.552 & 0.978 & 0.408 \\
LnTAsset & 0.045 & 0.066 & 0.000 & 0.751 \\
leverage & 0.020 & 0.237 & 0.000 & 0.002 \\
CFO & 0.000 & 0.000 & 0.7725 & 0.000 \\
R square & 0.5428 & 0.5308 & 0.7025 \\
\hline
\end{tabular}

Note. This above table shows the p-value. Observations: 288 (excluding outliers) $* *$ p-value is significant at the 0.05 level.

Table-10 reports the regression results for absolute unstandardized residuals for the energy sector from the year 2010-2012. Consistent with the regression results for the unstandardized residuals, this regression results reveal that for all four model Big4 audit firms and the non-executive director is not statistically significantly associated with earnings quality. Therefore this paper's hypotheses does is not supported. But, similar to the results of unstandardized residuals, absolute unstandardized residual also shows the association of CFO and earnings management. 
Table 10. Regression results for absolute unstandardized residuals (ABRES) (Energy sector, 2010-2012)

\begin{tabular}{lllll}
\hline Variables & MJ1 & MJ2 & PJ1 & PJ2 \\
\hline Big4 & .2100692 & .2589534 & -.0048768 & -0031908 \\
NExChair & .0072615 & .0225874 & -.0550969 & .045156 \\
Big4*NExChair & -.1234107 & -.1364979 & .0327144 & .05424 \\
LnTAsset & -.0070864 & -.0088828 & .00719 & .005287 \\
leverage & .006781 & -.0482215 & $-.39573 * *$ & .056658 \\
CFO & $-.8850044 * *$ & $-1.212452 * *$ & 0.2576 & $-.59059 * *$ \\
R square & 0.3061 & 0.3828 & 0.3222 \\
\hline
\end{tabular}

Note. This above table shows the coefficient value of the variables. Observations: 288 (excluding outliers) **p-value is significant at the 0.05 level.

\subsection{Sensitivity Analysis}

This paper also performs a sensitivity analysis to test the robustness of the study by splitting the sample at the median firm size using the total asset variable. First, the total asset is substituted with a dummy variable taking the value of 1 if the total assets more than the median value and taking value 0 if total assets are less than the median. Regressions are re-run for unstandardized residuals and absolute unstandardized residuals. Table 11 shows the coefficients and their significance level consistent with the result for the original regression. R-square value is higher in the performance adjusted modified Jones model than in the modified jones model and CFO has a significant association with earnings management.

Similarly, Table 12 shows the same results for coefficient and significant level of variables under the regression analysis of absolute unstandardized residuals. In short, none of the variables include firm size as statistically significant. Therefore, these results show that earnings management is not sensitive to firm size.

Table 11. Regression results for unstandardized residuals (Energy sector, 2010-2012)

Panel A Regression results for firms with total assets $>$ total asset median value

\begin{tabular}{|c|c|c|c|c|}
\hline Variable & MJ1 & MJ2 & PJ1 & PJ2 \\
\hline Big4 & .1584471 & .397059 & .122633 & .35390 \\
\hline NExChair & .127689 & .16849 & .07542 & .10551 \\
\hline Big4*NExChair & -.140952 & -.384544 & -.119040 & -.35814 \\
\hline LnTAsset & -.00984 & -.01541 & .00603 & .00371 \\
\hline leverage & .00348 & .19738 & $-.141016^{* *}$ & .02327 \\
\hline $\mathrm{CFO}$ & $-.58218 * *$ & $-.69088 * *$ & $-1.2951 * *$ & $-1.549 * *$ \\
\hline $\mathrm{R}$ square & 0.173 & 0.1413 & .6589 & 0.3493 \\
\hline \multicolumn{5}{|c|}{ Panel B Regression results for firms with total assets $<$ total asset median value } \\
\hline Variable & MJ1 & MJ2 & PJ1 & PJ2 \\
\hline Big4 & .406934 & .42750 & .05915 & .00845 \\
\hline NExChair & .02269 & .0549 & -.017851 & .00608 \\
\hline Big4*NExChair & -.220187 & -.26422 & -.03645 & -.04285 \\
\hline LnTAsset & -.422612 & -.50281 & .01262 & .02160 \\
\hline leverage & .71716 & .84276 & -.055539 & -.0882 \\
\hline $\mathrm{CFO}$ & $-1.1430 * *$ & $-1.447 * *$ & -.835950 & -1.0770 \\
\hline R square & 0.5246 & 0.5478 & 0.9455 & 0.9409 \\
\hline
\end{tabular}

Note. **p-value significant at 0.05 level. 
Table 12. Regression results for absolute unstandardized residuals (Energy sector, 2010-2012)

Panel A Regression results for firms with total assets $>$ total asset median value

\begin{tabular}{|c|c|c|c|c|}
\hline Variable & MJ1 & MJ2 & PJ1 & PJ2 \\
\hline Big4 & -.1572 & .18838 & .013281 & .188428 \\
\hline NExChair & -.12796 & -.11023 & -.056597 & -.03489 \\
\hline Big4*NExChair & .2051 & -.099227 & -.01313 & -.138275 \\
\hline LnTAsset & -.00964 & -.0147 & -.00674 & -.01446 \\
\hline leverage & .04901 & .07748 & $.14554 * *$ & $.15979 * *$ \\
\hline $\mathrm{CFO}$ & $.29908 * *$ & .270780 & $.62790 * *$ & .38210 \\
\hline R square & 0.1694 & 0.0932 & 0.3994 & 0.1351 \\
\hline \multicolumn{5}{|c|}{ Panel B Regression results for firms with total assets $<$ total asset median value } \\
\hline Variable & MJ1 & MJ2 & PJ1 & PJ2 \\
\hline Big4 & .52427 & .587241 & .241570 & .335423 \\
\hline NExChair & .13876 & .18536 & -.03063 & -.011992 \\
\hline Big4*NExChair & -.24667 & -.22643 & -.1190859 & -.196246 \\
\hline LnTAsset & -.34025 & -.41124 & -.0941 & -.125700 \\
\hline leverage & $.712179 * *$ & $.82480 * *$ & $.376254 * *$ & $.520471 * *$ \\
\hline $\mathrm{CFO}$ & $-1.09416^{* *}$ & $-1.403 * *$ & $-.36767 * *$ & $-.44352 * *$ \\
\hline $\mathrm{R}$ square & 0.4805 & 0.5028 & 0.5460 & 0.5639 \\
\hline
\end{tabular}

Note. ** P-value significant at 0.05 level.

This paper also performs additional sensitivity tests by excluding negative cash flow firms on the assumption that non-executive chairman or Big4 audit firm is irrelevant in a negative cash-flow firm. After exclusion of the negative cash flow firms' regression is run again for each model under unstandardized residual and absolute unstandardized residuals. The results are documented in table-13. The results reveal that after the exclusion of negative cash flow firm CFO and leverage shows statistically significant results, which might indicate these variables statistically significant association with earnings management.

Table 13. Regression results after excluding negative CFO firms (Energy sector, 2010-2012)

Panel A Regression results for unstandardized residuals

\begin{tabular}{lllll}
\hline Variable & MJ1 & MJ2 & PJ1 & PJ2 \\
\hline Big4 & -.004112 & .46202 & -.053756 & .40220 \\
NExChair & .011939 & .101787 & -.052241 & .02445 \\
Big4*NExChair & .010288 & -.48310 & .054906 & -.429349 \\
LnTAsset & -.021348 & -.02906 & -.00706 & -.011856 \\
leverage & .05436 & $.25164 * *$ & $-.128708^{* *}$ & .03106 \\
CFO & $1.2637 * *$ & $.95837 * *$ & $-.6884^{* *}$ & $-1.3937 * *$ \\
R square & 0.8178 & 0.6863 & 0.8688 & 0.7738 \\
\hline
\end{tabular}

Panel B Regression results for absolute unstandardized residuals

\begin{tabular}{lllll}
\hline Variable & MJ1 & MJ2 & PJ1 & PJ2 \\
\hline Big4 & -.02090 & .49186 & .03280 & .324983 \\
NExChair & .011349 & .01286 & .026435 & .04271 \\
Big4*NExChair & .055336 & -.42057 & -.028897 & -.30554 \\
LnTAsset & .009550 & .0045716 & .0041612 &. .00061 \\
leverage & $.081953 * *$ & .12067 & $.12649 * *$ & $.146147 * *$ \\
CFO & $1.14975^{* *}$ & $1.1354 * *$ & $.675638^{* *}$ & $.98172 * *$ \\
R square & 0.9228 & 0.7359 & 0.8814 & 0.8112 \\
\hline
\end{tabular}

Note. ${ }^{* *}$ p-value significant at 0.05 level.

\section{Discussion}

This paper examines the relationship between the non-executive board chairman and the earnings quality and 
also the relation of non-executive chairman on the board and Big 4 firm in earnings quality. In all four models, the coefficient for non-executive board chairman and Big4 is not significant. These findings are consistent with prior studies from Kao and Chen (2004), Davidson et al. (2005) and Lin (2011). These results suggest that depending on the diversification strategy taken by the firm's non-executive chairmanship, the audit quality does not influence the decision process of the daily operation of the firm. This might happen because a non-executive independent chairperson might not have daily contact or monitoring in the operation of the firm. The external audit quality also does not seem to influence the decision making of the firm. Researchers argue that when the management dominates or controls the boards and influences nominations of an independent chairman, then the non-executive directors' monitoring role might be questionable. Researchers also argue that independent chairman might lack expertise, skills and knowledge necessary for the monitoring role and that might affect their monitoring quality. Audit quality might also be in question if the audit firm's tenure with the client firm is for a long period. Audit quality might also be jeopardized if the external audit firm has a huge non-audit service with the audit client. These other factors might help to explain the insignificant findings found in this study.

This result might have implications for regulators and policymakers concerned to minimize the earnings management and improve financial report quality. The non-significant association audit quality proxies by big 4 audit firm and non-executive chairman and earnings management raise concerns on the effectiveness of these variables as external and internal monitoring mechanisms of corporate governance.

\section{Limitations and Future Research}

The first limitation visible in this paper is, this study examines the relationship between non-executive board chairpersons based on only energy sector firms, 293 firm-year observations from the year 2010-2012. This sample size is too small to study and limits the generalization of the results to other sectors as well. This small sample size also might have affected the results. Second, this paper assumes that the big 4 position and non-executive chairman position remained the same over the period, which again biases the selection and the assumption limits the interpretation of the results. Future studies can look at the earnings increasing or decreasing behavior considering a wide range of control variables. Studies can also look as board composition, board member skill and expertise and its effect on earnings management.

\section{References}

Becker, C. L., DeFond, M. L., Jiambalvo, J., \& Subramanyam, K. R. (1998). The effect of audit quality on earnings management. Contemporary Accounting Research, 15(1), 1-24. https://doi.org/10.1111/j.1911-3846.1998.tb00547.x

Cai, C., Zhao, S., \& Huang, Y. (2005). Toward the effect of Audit Quality on Earnings Management-Empirical evidence from manufacturing enterprises listed in Shangai Stock Market. Journal of Modern Accounting and Auditing, 1(2), 69-80.

Davidson, R. A., \& Neu, D. (1993). A note on the association between audit firm size and audit quality. Contemporary Accounting Research, 9(2), 479-488. https://doi.org/10.1111/j.1911-3846.1993.tb00893.x

Davidson, R., Goodwin-Stewart, J., \& Kent, P. (2005). Internal governance structures and earnings management. Accounting and Finance, 45, 1-27. https://doi.org/10.1111/j.1467-629x.2004.00132.x

DeAngelo, L. E. (1981). Auditor size and audit quality. Journal of Accounting and Economics, 3(3), 297-322. https://doi.org/10.1016/0165-4101 (81)90002-1

Kao, I., \& Chen, A. (2004). The effects of board characteristics on earnings management. Corporate Ownership and Control, 1(3), 96-107. https://doi.org/10.22495/cocv1i3p9

Kothari, S. P., Leone, A. J., \& Wesley, C. E. (2005). Performance matched discretionary accrual measures. Journal of Accounting and Economics, 39, 163-197. https://doi.org/10.1016/j.jacceco.2004.11.002

Lin, T. P. (2011). Corporate governance mechanisms and earnings management in transitional countries-Evidence from Chinese listed firms. A thesis submitted in fulfillment of requirements for the degree of Doctor of Philosophy.

Ow-Yong, K., \& Guan, C. K. (2000). Corporate governance codes: A comparison between Malaysia and the UK. Conference Papers, 8(2), 125-132. https://doi.org/10.1111/1467-8683.00190

$\mathrm{Wu}, \mathrm{S} .$, \& Li, Q. (2006). Audit quality of international big4, China big10, and non-big 10-empirical research on the Chinese listed firms in 2003. Contemporary Finance and Economics, 2, 112-118. 
Yasar, A. (2013). Big Four Auditors' Audit Quality and Earnings Management: Evidence from Turkish Stock Market. International Journal of Business and Social Science, 4(17).

\section{Appendix}

Table P1: Descriptive statistics for measurement of total accruals (in Energy Sector, Year: 2010-2012) (after exclusion of Unstanderdised Residuals $>3$ Std.Deviation)

\begin{tabular}{llllll}
\hline & $\mathrm{N}$ & Mean & Std. Deviation & Minimum & Maximum \\
\hline TA (method 1) & 398 & -.1645 & .4202551 & -5.489878 & 2.352868 \\
TA (method 2) & 398 & -.15322 & .5022095 & -5.489878 & 2.815867 \\
$\quad \Delta$ Sales & 398 & .01750 & .5022916 & -2.997428 & 7.526208 \\
1/laggedTAsset & 398 & $9.77 \mathrm{e}-08$ & $3.22 \mathrm{e}-07$ & $3.75 \mathrm{e}-11$ & $3.92 \mathrm{e}-06$ \\
PPE & 398 & .6564 & .6564025 & .0006511 & 6.148722 \\
ROA & 398 & .7317 & .7317828 & -6.200109 & 7.794192 \\
\hline
\end{tabular}
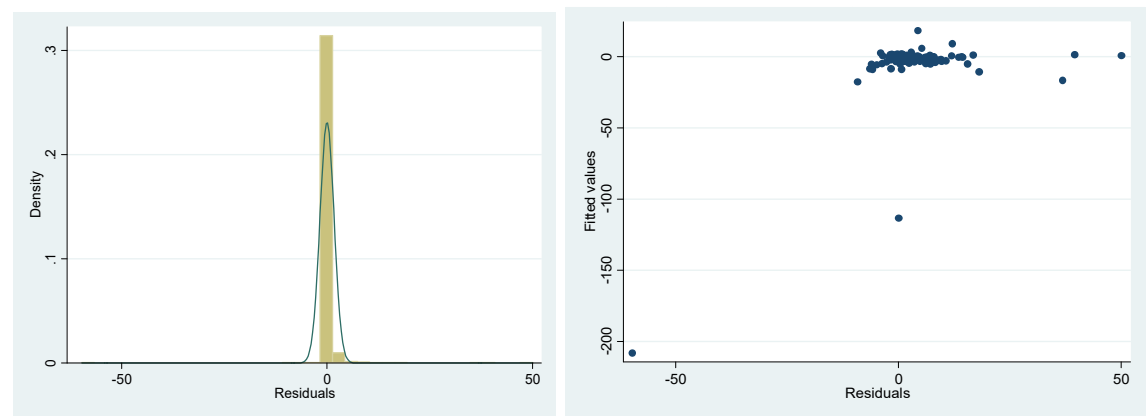

Figure 1. Normality test unstandardized residual under modified jones model - method 1(MJ1)
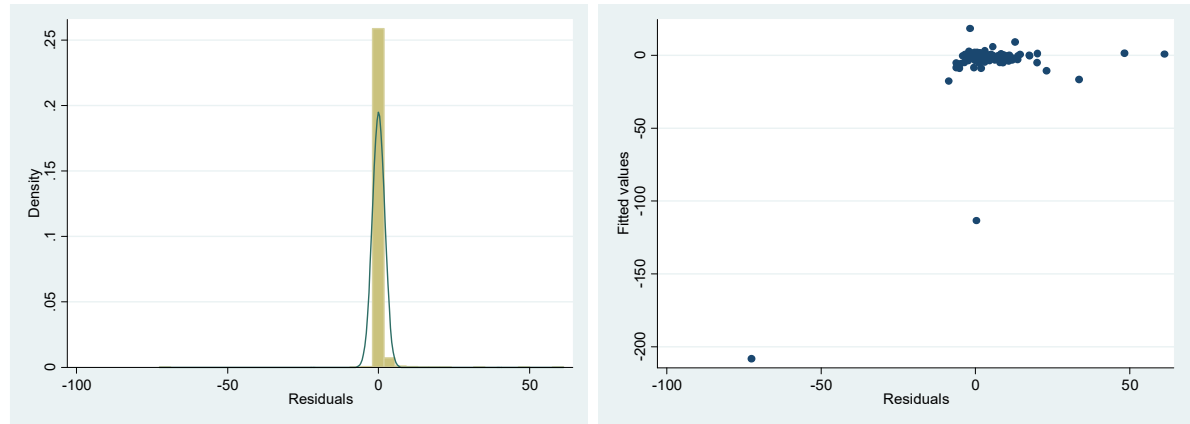

Figure 2. Normality test unstanderdized residual under modified jones model -method 2(MJ2)
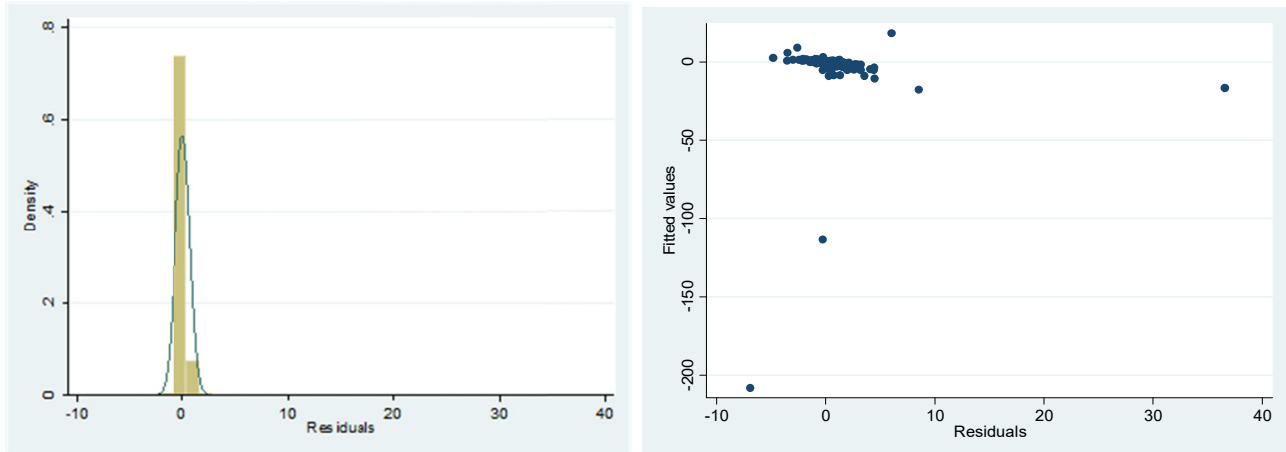

Figure 3. Normality test unstandardized residual under performance matched modified jones model -method 1 PJ (1) 


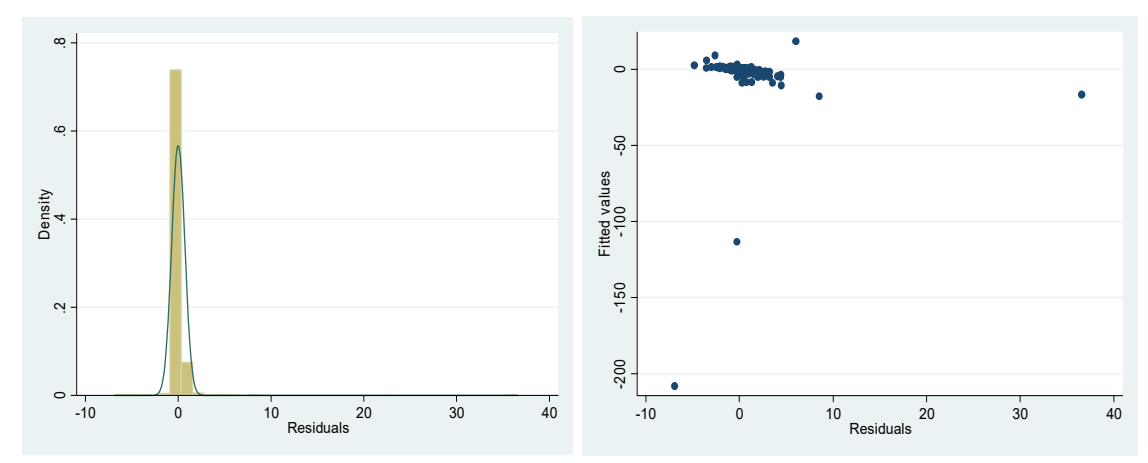

Figure 4. Unstanderdized residual under Performance matched Modified Jones Model -method 2(PJ2)

Table P2 Regression Results for energy sector from 2010-2012(after exclusion of outliers, unstandardized residuals)

Regression result for MJ1 (2010-2012)

\begin{tabular}{|c|c|c|c|c|c|c|}
\hline ta1_laga & Coef. & std. Err. & $t$ & $P>|t|$ & [95\% Conf & Interval] \\
\hline 1tasset & -332308.5 & 133337.7 & -2.49 & 0.014 & -596981.7 & -67635.24 \\
\hline lchgsales & .0453417 & .065317 & 0.69 & 0.489 & -.0843115 & .174995 \\
\hline lppe & .0452942 & .0271985 & 1.67 & 0.099 & -.0086945 & .0992829 \\
\hline _cons & -.1089715 & .0324219 & -3.36 & 0.001 & -.1733284 & -.0446146 \\
\hline ta1_laga & Coef. & Std. Err. & $\mathrm{t}$ & $P>|t|$ & [95\% Conf & Interval] \\
\hline 1tasset & -985709.4 & 173917.8 & -5.67 & 0.000 & -1331176 & -640243 \\
\hline 1chgsales & .1173654 & .1264093 & 0.93 & 0.356 & -.1337312 & .368462 \\
\hline 1ppe & .058564 & .0441759 & 1.33 & 0.188 & -.029186 & 1463141 \\
\hline _cons & -.1394584 & .0392301 & -3.55 & 0.001 & -.2173841 & -.0615326 \\
\hline ta1_laga & coef. & Std. Err. & $\mathrm{t}$ & $P>|t|$ & {$[95 \%$ conf } & Interva1] \\
\hline 1tasset & -1513268 & 171406.3 & -8.83 & 0.000 & -1853849 & -1172687 \\
\hline 1chgsales & -.2995714 & .0709401 & -4.22 & 0.000 & -.4405278 & -.158615 \\
\hline 1ppe & .0548318 & .0387589 & 1.41 & 0.161 & -.0221814 & 131845 \\
\hline _cons & -.060364 & .0370231 & -1.63 & 0.107 & -.133928 & .0132 \\
\hline
\end{tabular}

Regression result for MJ2 (2010-2012)

\begin{tabular}{r|rlrrrr}
\hline ta2_laga & Coef. & Std. Err. & $\mathrm{t}$ & $\mathrm{P}>|\mathrm{t}|$ & \multicolumn{2}{l}{ [95\% Conf. Interva1] } \\
\hline 1tasset & -344053.3 & 137537.5 & -2.50 & 0.014 & -617063.1 & -71043.64 \\
1chgsales & .0542918 & .0673743 & 0.81 & 0.422 & -.0794452 & .1880288 \\
1ppe & .0455551 & .0280552 & 1.62 & 0.108 & -.0101341 & .1012442 \\
-cons & -.1032525 & .0334431 & -3.09 & 0.003 & -.1696365 & -.0368686 \\
\hline
\end{tabular}

\begin{tabular}{r|rlrrrr}
\hline ta2_laga & Coef. & std. Err. & $\mathrm{t}$ & $\mathrm{P}>|\mathrm{t}|$ & \multicolumn{2}{c}{ [95\% Conf. Interva1] } \\
\hline 1tasset & -1044619 & 210449.1 & -4.96 & 0.000 & -1462650 & -626588.1 \\
1chgsales & .1966231 & .1529615 & 1.29 & 0.202 & -.1072161 & .5004622 \\
1ppe & .0262512 & .053455 & 0.49 & 0.625 & -.0799307 & .132433 \\
_cons & -.1114234 & .0474703 & -2.35 & 0.021 & -.2057174 & -.0171294 \\
\hline
\end{tabular}

\begin{tabular}{r|rlrrrr}
\hline ta2_laga & Coef. & std. Err. & $\mathrm{t}$ & $\mathrm{P}>|\mathrm{t}|$ & \multicolumn{2}{c}{ [95\% Conf. Interva1] } \\
\hline 1tasset & -1487927 & 181662.4 & -8.19 & 0.000 & -1848886 & -1126967 \\
1chgsales & -.2847676 & .0751848 & -3.79 & 0.000 & -.4341581 & -.1353771 \\
1ppe & .0572781 & .0410781 & 1.39 & 0.167 & -.0243432 & .1388993 \\
-cons & -.0687361 & .0392383 & -1.75 & 0.083 & -.1467018 & .0092296 \\
\hline
\end{tabular}




\section{Regression result for PJ1 (2010-2012)}

\begin{tabular}{|c|c|c|c|c|c|c|}
\hline ta1_1aga & coef. & Std. Err. & $\mathrm{t}$ & $P>|t|$ & {$[95 \%$ Conf } & f. Interval \\
\hline $\begin{array}{r}\text { 1tasset } \\
\text { 1chgsales } \\
1 \text { ppe } \\
\text { roa } \\
\text { _cons }\end{array}$ & $\begin{array}{r}445409 \\
-.0383268 \\
.0235624 \\
.6059296 \\
-.0614317\end{array}$ & $\begin{array}{l}139481.5 \\
.0512187 \\
.0210689 \\
.073727 \\
.0255791\end{array}$ & $\begin{array}{r}3.19 \\
-0.75 \\
1.12 \\
8.22 \\
-2.40\end{array}$ & $\begin{array}{l}0.002 \\
0.456 \\
0.266 \\
0.000 \\
0.018\end{array}$ & $\begin{array}{r}168503.1 \\
-.1400088 \\
-.0182647 \\
.459563 \\
-.1122127\end{array}$ & $\begin{array}{r}722314 . \\
.063355 \\
.065389 \\
.752296 \\
-.010650\end{array}$ \\
\hline ta1_1aga & Coef. & Std. Err. & $\mathrm{t}$ & $P>|t|$ & [95\% Conf. & Interva1] \\
\hline $\begin{array}{r}\text { 1tasset } \\
\text { 1chgsales } \\
1 \text { ppe } \\
\text { roa } \\
\text { _cons }\end{array}$ & $\begin{array}{r}741641.3 \\
-.1359536 \\
.0032951 \\
.7105717 \\
-.0647386\end{array}$ & $\begin{array}{l}182575.3 \\
.0823937 \\
.0281934 \\
.0601108 \\
.0254865\end{array}$ & $\begin{array}{r}4.06 \\
-1.65 \\
0.12 \\
11.82 \\
-2.54\end{array}$ & $\begin{array}{l}0.000 \\
0.102 \\
0.907 \\
0.000 \\
0.013\end{array}$ & $\begin{array}{r}378923.5 \\
-.2996431 \\
-.0527159 \\
-.591151 \\
-.1153719\end{array}$ & $\begin{array}{r}1104359 \\
.0277359 \\
.0593061 \\
.8299923 \\
-.0141052\end{array}$ \\
\hline ta1_laga & Coef. & Std. Err. & $\mathrm{t}$ & $P>|t|$ & [95\% Conf. & Interval] \\
\hline $\begin{array}{r}\text { tasset } \\
1 \text { chgsales } \\
1 \text { ppe } \\
\text { roa } \\
\text { _cons }\end{array}$ & $\begin{array}{l}-57100.67 \\
-.1722402 \\
-.0185724 \\
.5236932 \\
-.0151422\end{array}$ & $\begin{array}{l}217801.4 \\
.0555861 \\
.0305008 \\
.0630881 \\
.0284107\end{array}$ & $\begin{array}{r}-0.26 \\
-3.10 \\
-0.61 \\
8.30 \\
-0.53\end{array}$ & $\begin{array}{l}0.794 \\
0.003 \\
0.544 \\
0.000 \\
0.595\end{array}$ & $\begin{array}{r}-489935.2 \\
-.2827059 \\
-.0791864 \\
.3983189 \\
-.0716024\end{array}$ & $\begin{array}{r}375733.8 \\
-.0617746 \\
.0420416 \\
.6490676 \\
.0413181\end{array}$ \\
\hline
\end{tabular}

\section{Regression result for PJ2 (2010-2012)}

\begin{tabular}{r|rrrrrr}
\hline ta2_laga & Coef. & Std. Err. & $\mathrm{t}$ & $\mathrm{P}>|\mathrm{t}|$ & {$[95 \%$ Conf. } & Interva1] \\
\hline 1tasset & 449689.5 & 144945.3 & 3.10 & 0.003 & 161936.7 & 737442.2 \\
1chgsales & -.0311008 & .053225 & -0.58 & 0.560 & -.1367658 & .0745642 \\
1ppe & .0233755 & .0218942 & 1.07 & 0.288 & -.0200901 & .066841 \\
roa & .6184152 & .076615 & 8.07 & 0.000 & .4663151 & .7705153 \\
-cons & -.0547331 & .0265811 & -2.06 & 0.042 & -.1075033 & -.0019629 \\
\hline
\end{tabular}

\begin{tabular}{r|rlrrrr}
\hline ta2_laga & Coef. & std. Err. & $\mathrm{t}$ & $\mathrm{P}>|\mathrm{t}|$ & [95\% Conf. Interva1] \\
\hline 1tasset & 480486 & 290247.1 & 1.66 & 0.101 & -96140.53 & 1057113 \\
1chgsales & -.0270363 & .1309845 & -0.21 & 0.837 & -.2872598 & .2331872 \\
1ppe & -.0225467 & .0448201 & -0.50 & 0.616 & -.1115896 & .0664962 \\
roa & .6273749 & .0955605 & 6.57 & 0.000 & .4375274 & .8172225 \\
_cons & -.0454521 & .0405169 & -1.12 & 0.265 & -.125946 & .0350417 \\
\hline
\end{tabular}

\begin{tabular}{r|rrrrrr}
\hline ta2_1aga & Coef. & Std. Err. & $\mathrm{t}$ & $\mathrm{P}>|\mathrm{t}|$ & \multicolumn{2}{c}{ [95\% Conf. Interva1] } \\
\hline 1tasset & 50068.52 & 231452.4 & 0.22 & 0.829 & -409894.6 & 510031.6 \\
1chgsales & -.1502812 & .05907 & -2.54 & 0.013 & -.2676705 & -.032892 \\
1ppe & -.0202511 & .0324125 & -0.62 & 0.534 & -.0846641 & .044162 \\
roa & .5531217 & .0670422 & 8.25 & 0.000 & .4198894 & .686354 \\
_cons & -.020973 & .0301914 & -0.69 & 0.489 & -.080972 & .0390259 \\
\hline
\end{tabular}

Table P3. Regression result with cook distance $<3$

Regression result for MJ1 (2010-2012)

\begin{tabular}{|c|c|c|c|c|c|c|}
\hline ta1_1aga & coef. & Std. Err. & $\mathrm{t}$ & $P>|t|$ & [95\% conf. & Interval] \\
\hline $\begin{array}{r}\text { 1tasset } \\
\text { 1chgsales } \\
\text { 1ppe } \\
\text { _cons }\end{array}$ & $\begin{array}{r}-332308.5 \\
.0453417 \\
.0452942 \\
-.1089715\end{array}$ & $\begin{array}{r}133337.7 \\
.065317 \\
.0271985 \\
.0324219\end{array}$ & $\begin{array}{r}-2.49 \\
0.69 \\
1.67 \\
-3.36\end{array}$ & $\begin{array}{l}0.014 \\
0.489 \\
0.099 \\
0.001\end{array}$ & $\begin{array}{l}-596981.7 \\
-.0843115 \\
-.0086945 \\
-.1733284\end{array}$ & $\begin{array}{r}-67635.24 \\
.174995 \\
.0992829 \\
-.0446146\end{array}$ \\
\hline ta1_1aga & Coef. & Std. Err. & $\mathrm{t}$ & $P>|t|$ & [95\% Conf. & Interval] \\
\hline $\begin{array}{r}\text { 1tasset } \\
\text { 1chgsales } \\
1 \text { ppe } \\
\text { _cons }\end{array}$ & $\begin{array}{r}-258191.5 \\
.0746857 \\
.0791137 \\
-.1907935\end{array}$ & $\begin{array}{l}104106.5 \\
.1412997 \\
.0492758 \\
.0423891\end{array}$ & $\begin{array}{r}-2.48 \\
0.53 \\
1.61 \\
-4.50\end{array}$ & $\begin{array}{l}0.015 \\
0.598 \\
0.112 \\
0.000\end{array}$ & $\begin{array}{r}-464956 \\
-.2059478 \\
-.0187523 \\
-.2749818\end{array}$ & $\begin{array}{r}-51427.1 \\
.3553191 \\
.1769797 \\
-.1066051\end{array}$ \\
\hline ta1_1aga & Coef. & Std. Err. & $\mathrm{t}$ & $P>|t|$ & [95\% Conf. & Interval] \\
\hline $\begin{array}{r}1 \text { tasset } \\
\text { 1chgsales } \\
1 \text { ppe } \\
\text { _cons }\end{array}$ & $\begin{array}{r}-1513268 \\
-.2995714 \\
.0548318 \\
-.060364\end{array}$ & $\begin{array}{l}171406.3 \\
.0709401 \\
.0387589 \\
.0370231\end{array}$ & $\begin{array}{r}-8.83 \\
-4.22 \\
1.41 \\
-1.63\end{array}$ & $\begin{array}{l}0.000 \\
0.000 \\
0.161 \\
0.107\end{array}$ & $\begin{array}{r}-1853849 \\
-.4405278 \\
-.0221814 \\
-.133928\end{array}$ & $\begin{array}{r}-1172687 \\
-.158615 \\
.131845 \\
.0132\end{array}$ \\
\hline
\end{tabular}


Regression result for $\mathrm{MJ} 2$ (2010-2012)

\begin{tabular}{r|rlrrrr}
\hline ta2_laga & Coef. & Std. Err. & $\mathrm{t}$ & $\mathrm{P}>|\mathrm{t}|$ & [95\% Conf. Interva1] \\
\hline 1tasset & -344053.3 & 137537.5 & -2.50 & 0.014 & -617063.1 & -71043.64 \\
1chgsales & .0542918 & .0673743 & 0.81 & 0.422 & -.0794452 & .1880288 \\
7ppe & .0455551 & .0280552 & 1.62 & 0.108 & -.0101341 & .1012442 \\
-cons & -.1032525 & .0334431 & -3.09 & 0.003 & -.1696365 & -.0368686 \\
\hline
\end{tabular}

\begin{tabular}{r|rrrrrr}
\hline ta2_laga & Coef. & Std. Err. & $\mathrm{t}$ & $\mathrm{P}>|\mathrm{t}|$ & [95\% Conf. Interva1] \\
\hline 1tasset & -282118.6 & 122592.5 & -2.30 & 0.024 & -525597.8 & -38639.44 \\
1chgsales & .1518911 & .16639 & 0.91 & 0.364 & -.1785739 & .4823561 \\
1ppe & .047789 & .0580256 & 0.82 & 0.412 & -.0674549 & .1630328 \\
_cons & -.165227 & .049916 & -3.31 & 0.001 & -.2643645 & -.0660895 \\
\hline
\end{tabular}

\begin{tabular}{r|rlccrr}
\hline ta2_laga & Coef. & Std. Err. & $\mathrm{t}$ & $\mathrm{P}>|\mathrm{t}|$ & \multicolumn{2}{l}{ [95\% Conf. Interva1] } \\
\hline 1tasset & -1487927 & 181662.4 & -8.19 & 0.000 & -1848886 & -1126967 \\
1chgsa1es & -.2847676 & .0751848 & -3.79 & 0.000 & -.4341581 & -.1353771 \\
1ppe & .0572781 & .0410781 & 1.39 & 0.167 & -.0243432 & .1388993 \\
_cons & -.0687361 & .0392383 & -1.75 & 0.083 & -.1467018 & .0092296 \\
\hline
\end{tabular}

\section{Regression result for PJ1 (2010-2012)}

\begin{tabular}{|c|c|c|c|c|c|c|}
\hline ta1_1aga & Coef. & Std. Err. & $t$ & $P>|t|$ & [95\% Conf & - Interval] \\
\hline $\begin{array}{r}\text { 1tasset } \\
\text { 1chgsales } \\
1 \text { ppe } \\
\text { roa } \\
\text { _cons }\end{array}$ & $\begin{array}{r}445409 \\
-.0383268 \\
.0235624 \\
.6059296 \\
-.0614317\end{array}$ & $\begin{array}{l}139481.5 \\
.0512187 \\
.0210689 \\
.073727 \\
.0255791\end{array}$ & $\begin{array}{r}3.19 \\
-0.75 \\
1.12 \\
8.22 \\
-2.40\end{array}$ & $\begin{array}{l}0.002 \\
0.456 \\
0.266 \\
0.000 \\
0.018\end{array}$ & $\begin{array}{r}168503.1 \\
-.1400088 \\
-.0182647 \\
-.459563 \\
-.1122127\end{array}$ & $\begin{array}{r}722314.8 \\
.0633552 \\
.0653895 \\
.7522963 \\
-.0106507\end{array}$ \\
\hline ta1_1aga & Coef. & Std. Err. & $\mathrm{t}$ & $P>|t|$ & [95\% Conf. & Interval] \\
\hline $\begin{array}{r}\text { 1tasset } \\
\text { 1chgsales } \\
1 \text { ppe } \\
\text { roa } \\
\text { _cons }\end{array}$ & $\begin{array}{r}672651.4 \\
-.128698 \\
.0035431 \\
.6955716 \\
-.0640208\end{array}$ & $\begin{array}{l}87484.91 \\
.0802947 \\
.0280611 \\
.0487965 \\
.025318\end{array}$ & $\begin{array}{r}7.69 \\
-1.60 \\
0.13 \\
14.25 \\
-2.53\end{array}$ & $\begin{array}{l}0.000 \\
0.112 \\
0.900 \\
0.000 \\
0.013\end{array}$ & $\begin{array}{r}498873.3 \\
-.2881936 \\
-.0521969 \\
.5986433 \\
-.1143119\end{array}$ & $\begin{array}{r}846429.4 \\
.0307977 \\
.059283 \\
.7924999 \\
-.0137297\end{array}$ \\
\hline ta1_1aga & Coef. & Std. Err. & $\mathrm{t}$ & $P>|t|$ & [95\% Conf. & Interva1] \\
\hline $\begin{array}{r}\text { 1tasset } \\
\text { 1chgsales } \\
1 \text { ppe } \\
\text { roa } \\
\text { _cons }\end{array}$ & $\begin{array}{r}-57100.67 \\
-.1722402 \\
-.0185724 \\
.5236932 \\
-.0151422\end{array}$ & $\begin{array}{l}217801.4 \\
.0555861 \\
.0305008 \\
.0630881 \\
.0284107\end{array}$ & $\begin{array}{r}-0.26 \\
-3.10 \\
-0.61 \\
8.30 \\
-0.53\end{array}$ & $\begin{array}{l}0.794 \\
0.003 \\
0.544 \\
0.000 \\
0.595\end{array}$ & $\begin{array}{r}-489935.2 \\
-.2827059 \\
-.0791864 \\
.3983189 \\
-.0716024\end{array}$ & $\begin{array}{r}375733.8 \\
-.0617746 \\
.0420416 \\
.6490676 \\
.0413181\end{array}$ \\
\hline
\end{tabular}

\section{Regression result for PJ2 (2010-2012)}

\begin{tabular}{|c|c|c|c|c|c|c|}
\hline ta2_1aga & Coef. & Std. Err. & $t$ & $P>|t|$ & [95\% Conf. & - Interva1] \\
\hline $\begin{array}{r}1 \text { tasset } \\
\text { 1chgsales } \\
1 \text { ppe } \\
\text { roa } \\
\text { _cons }\end{array}$ & $\begin{array}{r}449689.5 \\
-.0311008 \\
.0233755 \\
.6184152 \\
-.0547331\end{array}$ & $\begin{array}{r}144945.3 \\
.053225 \\
.0218942 \\
.076615 \\
.0265811\end{array}$ & $\begin{array}{r}3.10 \\
-0.58 \\
1.07 \\
8.07 \\
-2.06\end{array}$ & $\begin{array}{l}0.003 \\
0.560 \\
0.288 \\
0.000 \\
0.042\end{array}$ & $\begin{array}{r}161936.7 \\
-.1367658 \\
-.0200901 \\
.4663151 \\
-.1075033\end{array}$ & $\begin{array}{r}737442.2 \\
.0745642 \\
.066841 \\
.7705153 \\
-.0019629\end{array}$ \\
\hline ta2_1aga & coef. & Std. Err. & $\mathrm{t}$ & $P>|t|$ & [95\% Conf. & Interval] \\
\hline $\begin{array}{r}7 \text { tasset } \\
\text { 1chgsales } \\
7 \text { ppe } \\
\text { roa } \\
\text { _cons }\end{array}$ & $\begin{array}{r}589048.7 \\
-.0384538 \\
-.0229369 \\
.6509791 \\
-.0465816\end{array}$ & $\begin{array}{r}139075.3 \\
.127645 \\
.0446089 \\
.0775721 \\
.0402482\end{array}$ & $\begin{array}{r}4.24 \\
-0.30 \\
-0.51 \\
8.39 \\
-1.16\end{array}$ & $\begin{array}{l}0.000 \\
0.764 \\
0.608 \\
0.000 \\
0.250\end{array}$ & $\begin{array}{r}312792.7 \\
-.2920049 \\
-.111547 \\
.4968916 \\
-.1265297\end{array}$ & $\begin{array}{l}865304.6 \\
.2150973 \\
.0656732 \\
.8050665 \\
.0333665\end{array}$ \\
\hline ta2_1aga & Coef. & Std. Err. & $\mathrm{t}$ & $P>|t|$ & [95\% Conf. & Interva1] \\
\hline $\begin{array}{r}\text { 1tasset } \\
\text { 1chgsales } \\
1 \text { ppe } \\
\text { roa } \\
\text { _cons }\end{array}$ & $\begin{array}{r}50068.52 \\
-. .1502812 \\
-.0202511 \\
.5531217 \\
-.020973\end{array}$ & $\begin{array}{r}231452.4 \\
.05907 \\
.0324125 \\
.0670422 \\
.0301914\end{array}$ & $\begin{array}{r}0.22 \\
-2.54 \\
-0.62 \\
8.25 \\
-0.69\end{array}$ & $\begin{array}{l}0.829 \\
0.013 \\
0.534 \\
0.000 \\
0.489\end{array}$ & $\begin{array}{r}-409894.6 \\
-.2676705 \\
-.0846641 \\
.4198894 \\
-.080972\end{array}$ & $\begin{array}{r}510031.6 \\
-.032892 \\
.044162 \\
.686354 \\
.0390259\end{array}$ \\
\hline
\end{tabular}


Table P4: Descriptive statistics of the outliers from energy sector from year 2010-2012

\begin{tabular}{r|rrrrr} 
Variable & obs & Mean & Std. Dev. & Min & Max \\
\hline ta1_laga & 5 & .0649442 & 1.333295 & -1.118283 & 2.352868 \\
ta2_laga & 5 & .6776549 & 1.782097 & -1.118283 & 2.815867 \\
lchgsales & 5 & 1.055386 & 3.741104 & -2.214662 & 7.526208 \\
1ppe & 5 & .2046109 & .3158112 & .009563 & .755222 \\
1tasset & 5 & $1.49 \mathrm{e}-06$ & $1.16 \mathrm{e}-06$ & $3.84 \mathrm{e}-08$ & $2.91 \mathrm{e}-06$ \\
\hline roa & 5 & -.4676217 & 4.861766 & -3.968311 & 7.794192 \\
tota1as 5090 & 5 & $3.41 \mathrm{e}+07$ & $5.88 \mathrm{e}+07$ & 456173 & $1.39 \mathrm{e}+08$ \\
netcash 9100 & 5 & 37631.1 & 2400964 & -2767853 & 2997019 \\
leverage & 5 & 2.100346 & 3.662797 & .1402082 & 8.586584
\end{tabular}

\begin{tabular}{r|rrrrr} 
Variable & obs & Mean & Std. Dev. & Min & Max \\
\hline ta1_laga & 288 & -.1349939 & .2846312 & -2.394068 & 1.12879 \\
ta2_laga & 288 & -.1324852 & .3053142 & -2.394068 & 1.354723 \\
1chgsales & 288 & .0030034 & .3205771 & -2.997428 & 2.2917 \\
1ppe & 288 & .6502904 & .7125566 & .0006511 & 6.148722 \\
1tasset & 288 & $6.93 \mathrm{e}-08$ & $1.56 \mathrm{e}-07$ & $3.75 \mathrm{e}-11$ & $1.06 \mathrm{e}-06$ \\
\hline roa & 288 & -.18356 & .4381694 & -3.330972 & 1.496506 \\
tota1as 5090 & 288 & $1.10 \mathrm{e}+09$ & $3.82 \mathrm{e}+09$ & 343115 & $2.80 \mathrm{e}+10$ \\
netcash 9100 & 288 & $7.22 \mathrm{e}+07$ & $3.41 \mathrm{e}+08$ & $-5.89 \mathrm{e}+08$ & $3.35 \mathrm{e}+09$ \\
1everage & 288 & .3635462 & .4875468 & .006456 & 4.635591
\end{tabular}

\section{Notes}

Note 1. Kothari et al. (2005) use Net Income before interest and tax and scaled it by the average total assets, but in this paper for simplicity of calculations and lack of sufficient data EBIT is scaled by lagged total asset.

\section{Copyrights}

Copyright for this article is retained by the author(s), with first publication rights granted to the journal.

This is an open-access article distributed under the terms and conditions of the Creative Commons Attribution license (http://creativecommons.org/licenses/by/4.0/). 